\title{
Arsenic in rice agrosystems (water, soil and rice plants) in Guayas and Los Ríos provinces, Ecuador
}

\author{
X.L. Otero ${ }^{\mathrm{a}, \mathrm{b}, *}$, W. Tierra ${ }^{\mathrm{b}}$, O. Atiaga $^{\mathrm{c}}$, D. Guanoluisa ${ }^{\mathrm{b}}$, L.M. Nunes $^{\mathrm{d}}$, T.O. Ferreira $^{\mathrm{e}}$, J. Ruales ${ }^{\mathrm{b}}$ \\ a Departamento de Edafoloxía e Química Agrícola, Facultade de Bioloxía, Universidade de Santiago de Compostela, Campus Sur, 15782 Santiago de Compostela, Spain \\ b Departamento de Ciencia de los Alimentos y Biotecnología, Escuela Politécnica Nacional, Quito, Ecuador \\ c Departamento de Ciencias de la Tierra y la Construcción, Universidad de las Fuerzas Armadas ESPE, Av. General Rumiñahui s/n, Sangolquí, P.0. Box 171-5-231B, Ecuador \\ d Faculdade de Ciências e Tecnologia, Universidade do Algarve, Campus de Gambelas, Faro, Portugal \\ e Departamento de Ciencia do Solo, Escola Superior de Agronomia Luiz Queiroz (ESALQ), Universidade de Sao Paulo, Brazil
}

\section{H I G H L I G H T S}

- Arsenic concentration in rice grains differed between provinces.

- Amorphous Fe oxyhydroxides limit assimilation of arsenic by rice.

- Physiological processes in rice plants may limit arsenic accumulation in the grains.

- Inorganic arsenic is the dominant form of the element in the rice plant.

\section{A R T I C L E I N F O}

\section{Article history:}

Received 5 June 2016

Received in revised form 21 August 2016

Accepted 22 August 2016

Available online $\mathrm{xxxx}$

\section{Editor: F.M. Tack}

\section{Keywords:}

Arsenic speciation

Plant tissues

Amorphous Fe oxyhydroxides

\section{G R A P H I C A L A B S T R A C T}

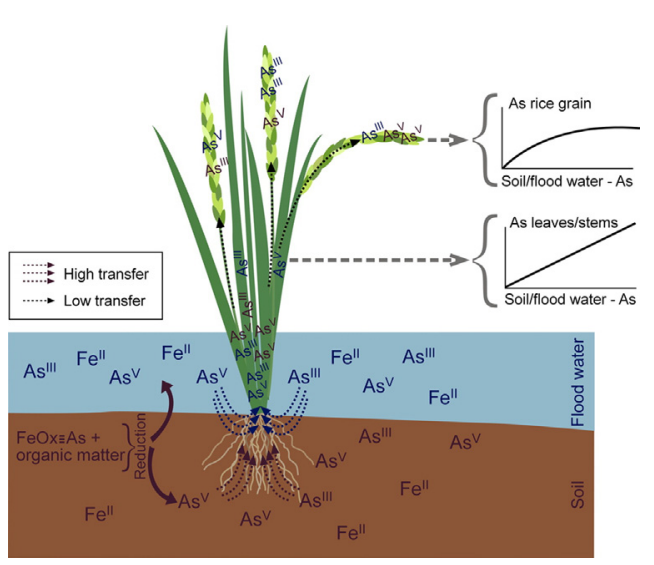

\footnotetext{
* Corresponding author at: Departamento de Edafoloxía e Química Agrícola, Facultade de Bioloxía, Universidade de Santiago de Compostela, 15782 Santiago de Compostela, Spain. E-mail address: xl.otero@usc.es (X.L. Otero).
} 
not necessarily imply accumulation of the element in the grain. The iAs form was dominant $(>80 \%)$ in all parts of the rice plants.

\section{Introduction}

Arsenic (As) is considered one of the most important toxic elements found in the environment because of its potential risk to ecosystems and to human health. Inorganic arsenic in drinking water is included in the highest health hazard category (group 1 carcinogen) (Naidu et al., 2006; National Research Council, 2001), and there is substantial evidence that this form of the element increases the risk of different types of cancers (bladder, lung, skin, and prostate; Zavala and Duxbury, 2008; Meharg and Zhao, 2012).

Wide spread intoxication by geogenic As was initially reported in Southeastern Asia and was associated with high concentrations of the element in groundwater (Mandal and Suzuki, 2002; Henke, 2009). However, more recent studies have reported the presence of hydroarsenicism in South America, especially in Argentina, as a consequence of high concentrations of As in the Chaco-Pampean plain aquifer due to desorption of the element from Fe oxyhydroxides (Nicolli et al., 2012; Bundschuh et al., 2012a). This aquifer, which is one of the largest in South America, extends over an area of 1 million $\mathrm{km}^{2}$. The number of people in South America potentially at risk of being affected by arsenic is around 2.6-3.4 million, distributed over Argentina, Chile, México and Perú; however, no background information is available for most countries, including Ecuador (McClintock et al., 2012). Thus, the extent of the problem (i.e. the number of people affected and the true risk associated with chronic As toxicity) remains unknown (Bundschuh et al., 2012b). The lack of information on geogenic As contamination in South America was recognized in a recent special issue of this journal (STOTEN no 429, 2012) dealing with occurrence, health effects and mitigation of As in South America (Bundschuh et al., 2012a, 2012b). Studies of the extent and severity of exposure to As through drinking water are scarce and even less is known about uptake of the element through the food chain (Bundschuh et al., 2012b).

Information about As contamination in Ecuador is especially scarce, relative to that regarding neighbouring countries such as Bolivia, Chile or Peru, where the problem has been reported (see e.g. Bundschuh et al., 2012a). In Ecuador, high concentrations of As in water have been associated with hydrothermal processes in volcanic regions, such as the thermal water of the Papallacta lagoon (39-10,560 $\left.\mu \mathrm{g} \mathrm{l}{ }^{-1}\right)$ and the Papallacta basin (1090-7852 $\left.\mu \mathrm{g} \mathrm{l}^{-1}\right)$. Other examples are the drinking water wells in Tumbaco and Guayllabamba (9-125 $\mathrm{g} \mathrm{l}^{-1}$ ), in most of the Sierra provinces (De La Torre et al., 2004; Cumbal et al., 2010; Bundschuh et al., 2012a) and the mining activity in Oro province. In the latter case, the presence of high concentrations of As in water (2.0-46,049 $\left.\mu \mathrm{g} \mathrm{l}^{-1}\right)$ and of other toxic metals in various rivers affected by artisanal gold extraction in Ponce Enríquez, Portovelo-Zaruma and Nambija has been reported (Appleton et al., 2001).

The extent of the intake of As through food is largely unknown. Although the As contents of various types of samples (water, soil, > 20 vegetables, meat, fish, prepared products, etc.) have been reported (Bundschuh et al., 2012c), no information was given about the As content of rice from South America.

Rice (Oryza sativa) is the staple food for more than half of the world's population (Meharg and Zhao, 2012) and is especially important in Asia (mean consumption, 250-650 g/person/day) and South America (120 g/person/day). Ecuador is the third biggest consumer, after Guayana and Surinam, with a mean consumption of $129 \mathrm{~g} /$ person/day (FAO, 2004; Meharg and Zhao, 2012). However, rice is an efficient accumulator of As (Meharg and Zhao, 2012). The high concentrations reached in the plant, even higher than in drinking water, lead to consumption of rice being the main route of ingestion of As (FAO, 2004; Zhao et al., 2010; Zavala and Duxbury, 2008).

The present study provides new information about the As concentrations in rice (grain, stem, leaf and husk) grown in the two main rice-producing provinces in Ecuador relative to As concentrations in soil and flood water and soil properties. To obtain this information, we analysed a large variety of samples, including water (from wells and irrigation channels, as well as flood and interstitial water) soils and different parts of the rice plants (stem, leaves and grain).

\section{Material and methods}

\subsection{Sampling}

Sampling was carried out in the provinces of Guayas and Los Ríos (Fig. 1), where rice production $(1,474,112 \mathrm{Mg}$ ) represents $>93 \%$ of total rice production in Ecuador (INEC, 2013). The sampling design took into consideration the local lithology, mainly formed by alluvial deposits (Torres and Marin, 1974), and hydrology. Both provinces are included in the River Guayas basin, which drains geologically diverse areas characterized by the presence of granites and basalts (Torres and Marin, 1974).

A total of 73 water samples were collected. Of these, 36 were samples of flood water from the rice fields and 16 were obtained from irrigation channels, 12 from wells and 9 from rivers close to cultivated fields. The samples were collected in polypropylene bottles $(500 \mathrm{ml})$ and were stored in a portable fridge at a temperature of approximately $4-8{ }^{\circ} \mathrm{C}$ during the sampling period. At the end of the day, the samples were filtered through a nitrocellulose filter ( $0.45 \mu \mathrm{m}$ pore size). The filtered sample was acidified $(\mathrm{pH}<2)$ using $50 \mu \mathrm{l}$ of a solution of $\mathrm{HNO}_{3}$ (6 M).

We obtained 50 composite soil samples from the superficial layers $(0-20 \mathrm{~cm})$. Each soil sample was produced by mixing 5 sub-samples $(\sim 500 \mathrm{~g})$ taken from different parts of the cultivated site. In the laboratory one subsample of the soil was dried at $45{ }^{\circ} \mathrm{C}$ and sieved through a $2 \mathrm{~mm}$ mesh. Another subsample was frozen at $-10{ }^{\circ} \mathrm{C}$ until analysis. A third subsample was used to extract the interstitial water by centrifugation at $6000 \mathrm{rpm}$ and $4{ }^{\circ} \mathrm{C}$.

We also collected 26 composite rice plant samples (with grain). The rice plant samples were produced by mixing 5-8 plants collected at the same points where the soil samples were obtained. Once in the laboratory, the plant samples were washed 3-5 times with distilled water. The dehusked rice grain (field grain) was separated, and the stem, leaves and rice husks were dried at $45^{\circ} \mathrm{C}$, ground and preserved in plastic bags until analysis. In addition, 16 samples of white (polished) commercial rice (market rice), produced in Ecuador, were analysed to determine tAs. In addition, arsenic fractioning was carried out in three of these samples. For this purpose, the samples were washed five times with ultra-pure water (Millipore, Brussels, Belgium), dried at $40{ }^{\circ} \mathrm{C}$ and stored in polypropylene containers until analysis.

\subsection{Chemical analysis of water and soil}

The $\mathrm{pH}$, redox potential (Eh) and electrical conductivity were determined in situ with portable electrodes (HANNA instruments INC, Woonsocket, RI, U.S.A.). The Eh values were corrected by adding the potential of a reference electrode $(+244 \mathrm{mV})$. The concentrations of dissolved As were determined by quadrupole ICP-MS (Agilent $7700 \times$, 


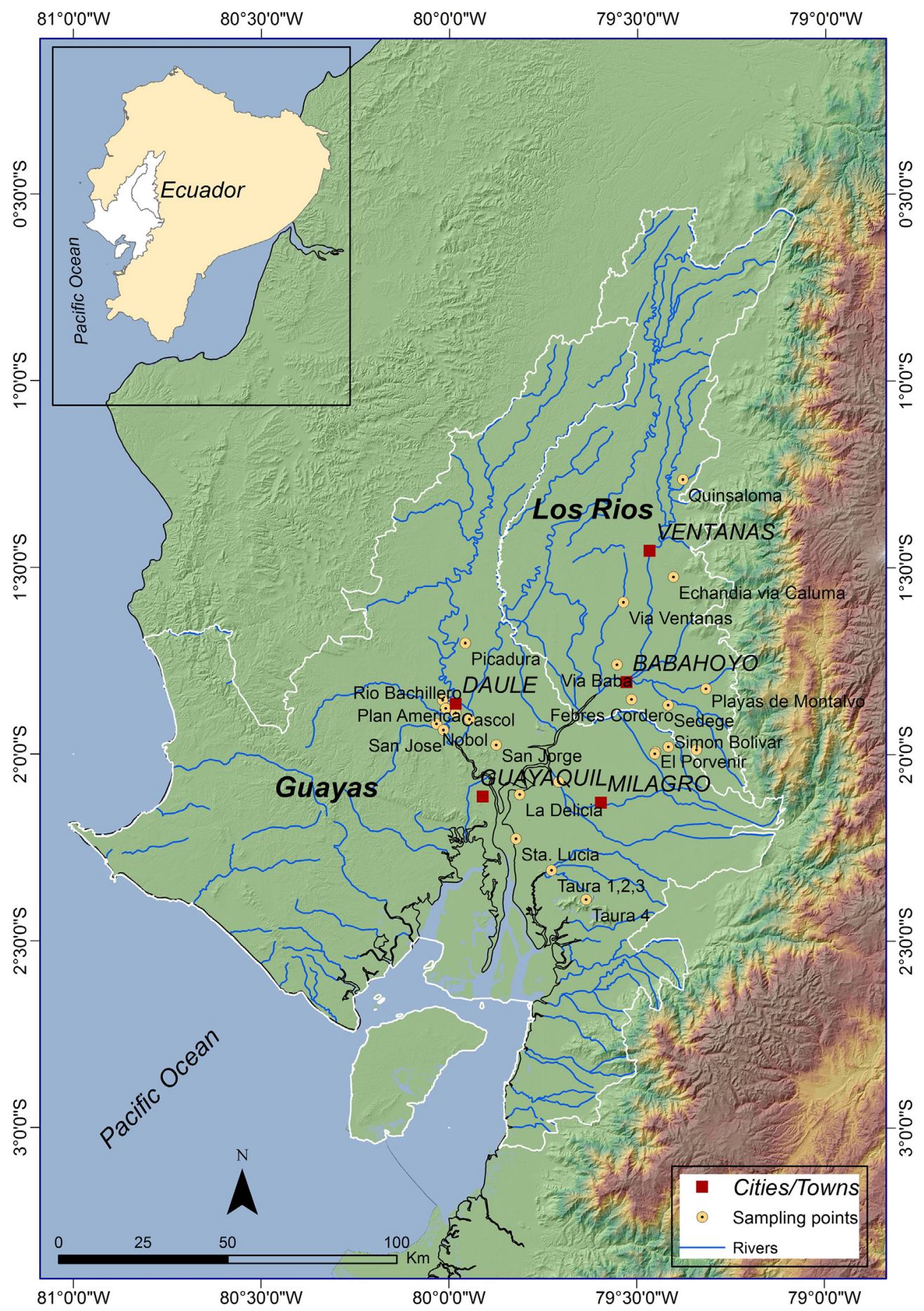

Fig. 1. Study site and location of sampling points.

Agilent Technologies, Palo Alto, CA, U.S.A.). In parallel to analysis of the samples, a recovery test was performed using certified material (Environment EP-H-1 drinking water, certified reference material, SP Science, Canada). Recovery of the certified concentration of dissolved As ranged between 91.7 and 103\%. The limit of detection (DL) was $1 \mu \mathrm{g} \mathrm{l} \mathrm{l}^{-1}$, determined as 2.5 times the standard error of the blank (Bruland et al., 1979).

Total organic carbon (TOC) was determined in previously ground soil samples, in a Leco100 S-C 144DR analyser (LECO Corporation, St.
Joseph MI, U.S.A.). Particle size was determined using the pipette method, following Gee and Bauder (1986). Bioavailable As ( $\mathrm{As}_{\mathrm{Me}}$ ) was extracted by the Mehlich 3 method (Mehlich, 1984). Amorphous Fe oxyhydroxides $\left(\mathrm{Fe}_{\mathrm{Ox}}\right)$ were extracted with an ammonium oxalate solution (0.2 M; pH 3; Sigma Aldrich St. Louis, MO, U.S.A.) (Blakemore, 1978). Acid digestion of the soil samples was performed (9 ml $\mathrm{HNO}_{3}: 3 \mathrm{ml} \mathrm{HCl}$, Merck, Darmstadt, Germany) in a microwave oven for 20 min to determine tAs. The tAs and $\mathrm{As}_{\mathrm{Me}}$ concentrations were determined by ICP-OES (Perkin Elmer, Optima model 4300 DV, Sunnyvale, 
Table 1

Physicochemical properties and As concentration in water samples. na: not analyzed.

\begin{tabular}{|c|c|c|c|c|c|c|c|c|}
\hline \multirow{2}{*}{$\frac{\text { Samples }}{\text { Waters }}$} & \multicolumn{4}{|c|}{ Guayas province } & \multicolumn{4}{|c|}{ Los Ríos province } \\
\hline & $\mathrm{pH}$ & $\begin{array}{l}\text { Eh } \\
(\mathrm{mV})\end{array}$ & $\begin{array}{l}\text { Elect. cond. } \\
\left(\mathrm{dS} \mathrm{m}^{-1}\right)\end{array}$ & $\begin{array}{l}\text { As dis. } \\
\left(\mu \mathrm{g} \mathrm{l}^{-1}\right)\end{array}$ & $\mathrm{pH}$ & $\begin{array}{l}\text { Eh } \\
(\mathrm{mV})\end{array}$ & $\begin{array}{l}\text { Elect. cond. } \\
\left(\mathrm{dS} \mathrm{m}^{-1}\right)\end{array}$ & $\begin{array}{l}\text { As dis. } \\
\left(\mu \mathrm{g} \mathrm{l}^{-1}\right)\end{array}$ \\
\hline Interstitial & n.a. & n.a. & n.a. & $\begin{array}{l}2.11 \pm 1.04 \\
(0.92-5.25) \\
(n=15)\end{array}$ & n.a. & n.a. & n.a. & $\begin{array}{l}1.03 \pm 0.23 \\
(0.74-1.23) \\
n=6\end{array}$ \\
\hline Flooding & $\begin{array}{l}7.8 \pm 0.6 \\
(6.4-9.0) \\
n=23\end{array}$ & $\begin{array}{l}372 \pm 81 \\
(260-438) \\
n=23\end{array}$ & $\begin{array}{l}0.82 \pm 0.80 \\
(0.23-3.81) \\
n=14\end{array}$ & $\begin{array}{l}3.07 \pm 4.08 \\
(0.64-19.01) \\
n=23\end{array}$ & $\begin{array}{l}7.6 \pm 0.7 \\
(6.5-9.0) \\
n=15\end{array}$ & $\begin{array}{l}432 \pm 62 \\
(324-520) \\
n=12\end{array}$ & $\begin{array}{l}0.21 \pm 0.15 \\
(0.08-0.50) \\
n=12\end{array}$ & $\begin{array}{l}1.42 \pm 0.23 \\
(0.13-4.49) \\
n=18\end{array}$ \\
\hline Well & $\begin{array}{l}7.2 \pm 0.8 \\
(6.4-8.0) \\
n=13\end{array}$ & $\begin{array}{l}386 \pm 49 \\
(260-438) \\
n=13\end{array}$ & $\begin{array}{l}0.42 \pm 0.13 \\
(0.20-0.58) \\
n=12\end{array}$ & $\begin{array}{l}3.19 \pm 1.40 \\
(1.28-5.84) \\
n=11\end{array}$ & $\begin{array}{l}6.9 \pm 0.1 \\
(6.9-7.2) \\
n=3\end{array}$ & $\begin{array}{l}461 \pm 17 \\
(449-485) \\
n=3\end{array}$ & $\begin{array}{l}0.41 \pm 0.18 \\
(0.25-0.68) \\
n=3\end{array}$ & $\begin{array}{l}0.88 \pm 0.28 \\
(0.68-1.08) \\
n=4\end{array}$ \\
\hline Irrigation canal & $\begin{array}{l}7.6 \pm 0.7 \\
(6.2-9.0) \\
n=15\end{array}$ & $\begin{array}{l}387 \pm 118 \\
(86-539) \\
n=15\end{array}$ & $\begin{array}{l}0.74 \pm 1.15 \\
(0.12-4.61) \\
n=12\end{array}$ & $\begin{array}{l}3.52 \pm 1.92 \\
(0.76-12.80) \\
n=13\end{array}$ & $\begin{array}{l}8.1 \pm 0.9 \\
(7.4-8.8) \\
n=4\end{array}$ & $\begin{array}{l}381 \pm 53 \\
(344-419) \\
n=4\end{array}$ & $\begin{array}{l}0.15 \pm 0.04 \\
(0.12-0.18) \\
n=4\end{array}$ & $\begin{array}{l}1.89 \pm 1.91 \\
(0.54-3.24) \\
n=4\end{array}$ \\
\hline Rivers & $\begin{array}{l}7.8 \pm 0.5 \\
(7.3-8.7) \\
n=7\end{array}$ & $\begin{array}{l}399 \pm 74 \\
(248-460) \\
n=7\end{array}$ & $\begin{array}{l}0.56 \pm 0.47 \\
(0.10-1.25) \\
n=6\end{array}$ & $\begin{array}{l}1.17 \pm 0.73 \\
(0.49-2.64) \\
n=7\end{array}$ & $\begin{array}{l}7.0 \\
n=1\end{array}$ & $\begin{array}{l}464 \\
n=1\end{array}$ & $\begin{array}{l}0.09 \\
n=1\end{array}$ & $\begin{array}{l}3.60 \\
(0.15-7.44) \\
n=2\end{array}$ \\
\hline
\end{tabular}

CA, U.S.A.). To validate the method of extracting tAs, certified soil standards were used (SRM 2709a, SMR2710a, SRM 2711a from NIST, U.S.A.) and the rate of As recovery was above $92 \%$.

\subsection{Plant analysis}

The tAs content was determined by digesting all plant material with a mixture of $\mathrm{HNO}_{3}$ (65\%, Merck, Darmstadt, Germany) and concentrated $\mathrm{HCl}$ (37\%, Merck, Darmstadt, Germany) of ultrapure quality (3 ml $\mathrm{HNO}_{3}: 1 \mathrm{ml} \mathrm{HCl}$ ) in an Ethos Plus Microwave Labstation (Milestone INC, Shelton, CT, U.S.A.). The tAs content was determined by ICP-MS (Agilent Technologies, Palo Alto, CA, U.S.A.). In parallel, the concentration was determined in a certified standard sample of rice flour (SMR rice flour $1568 \mathrm{~b}$ from the NIST, U.S.A.) with a rate of recovery of $102 \pm 3 \%(n=3)$.

Arsenic fractioning in the plant was carried out according to the method of Huang et al. (2010). Two grams of each plant sample (dry weight) was extracted with $15 \mathrm{ml}$ of $0.28 \mathrm{M} \mathrm{HNO}_{3}$ (65\%, Merck), by heating the samples to $95^{\circ} \mathrm{C}$ for $90 \mathrm{~min}$. The samples were then centrifuged at $10,000 \mathrm{rpm}$ at $4{ }^{\circ} \mathrm{C}$ for $20 \mathrm{~min}$, and the supernatant was filtered through a $0.45 \mu \mathrm{m}$ filter. Inorganic As (iAs: $\sum$ As III, As V) and organic As (oAs: $\sum$ DMA; MMA) were analysed in an HPLC (Varian Prostar, Spectralab Scientific, Toronto, Canada) coupled to an ICP-MS system (Varian $820-\mathrm{MS}$ ). The DL was $3.75 \mu \mathrm{g} \mathrm{kg}^{-1}$ for the inorganic forms and $1.35-4.35 \mu \mathrm{g} \mathrm{kg}^{-1}$ for the organic forms. The rate of recovery was $118 \pm 7 \%(n=6)$ for iAs and $127 \pm 6 \%(n=6)$ for oAs.

All material used during sampling and laboratory analysis was carefully washed in acid to prevent contamination of the samples. The material was immersed in a solution of $10 \% \mathrm{HCl}$ at least overnight and subsequently washed twice with distilled water and Milli-Q water (Millipore, Brussels, Belgium).

\subsection{Data analysis}

One-way ANOVA and a post-hoc U Mann-Whitney test were used to test for any differences between sites. Prior to ANOVA, all variables were checked for normality and homoscedasticity. Non-normally distributed data were transformed by natural logarithms, except for the percentage data for total $C$ content, which were subjected to an arcsine transformation (Zar, 1996). The relationships between the different variables were tested using Spearman's monotonic correlation coefficient (rs) for nonnormal variables, and linear relationships were tested with Pearson's ( $r$ ) for normally-distributed data. All statistical analyses were carried out using SigmaStat 2.0.

\section{Results}

\subsection{Water and soil samples: properties and composition}

\subsubsection{Water samples}

The $\mathrm{pH}$ of all samples was very similar, ranging between 7 and 8 (Table 1$)$. Unusually high values $(\mathrm{pH} \sim 9)$ were observed in some samples from the irrigation canal and flood water, presumably due to photosynthetic activity. Algae present in the water consume $\mathrm{CO}_{2}$ during photosynthesis, thus leading to an increase in the $\mathrm{pH}$ (Wetzel, 2001). The redox potential values mainly indicated oxic conditions (Eh $>350 \mathrm{mV}$ ), except in a few cases, which indicated anoxic conditions (Eh $<100 \mathrm{mV}$ ). Well water samples showed similar geochemical properties (Table 1 ). On the other hand, electrical conductivity was generally low (EC $<1 \mathrm{dS} \mathrm{m}^{-1}$ ), indicating low ionic concentration; however, the irrigation and flood water samples, which were taken from areas closer to the river Guayas estuary, indicated more brackish conditions (EC: 2$4 \mathrm{dS} \mathrm{m}^{-1}$; see e.g. Ayers and Westcot, 1994).

The concentrations of dissolved As in irrigation, flood and well water were below $<10 \mu \mathrm{g} \mathrm{l}^{-1}$, the maximum limit recommended for drinking water according to the World Health Organization (WHO, 2004). An exception was observed for samples taken from the Taura site, where values ranged between 12 and $19 \mu \mathrm{g} \mathrm{l}^{-1}$. Nevertheless, these values are well below the maximum concentration $\left(100 \mu \mathrm{g} \mathrm{l}^{-1}\right)$ permitted by the FAO and by the Ecuadorian legislation for irrigation water (Ayers and Westcot, 1994). The concentration of As in the interstitial water $\left(2.11 \pm 1.04 \mu \mathrm{g} \mathrm{l}^{-1}\right)$ was also well below the limit of toxicity established

Table 2

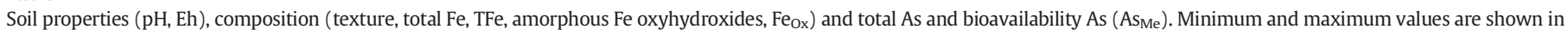
brackets.

\begin{tabular}{|c|c|c|c|c|c|c|c|c|c|c|}
\hline \multirow{2}{*}{ Sample } & \multirow{2}{*}{$\mathrm{pH}$} & \multirow{2}{*}{$\frac{\mathrm{Eh}}{\mathrm{mV}}$} & \multirow{2}{*}{$\frac{\mathrm{TOC}}{\%}$} & \multirow{2}{*}{ Clay } & \multirow{2}{*}{ Silt } & \multirow{2}{*}{ Sand } & \multirow{2}{*}{ TFe } & $\mathrm{Fe}_{\mathrm{Ox}}$ & \multirow{2}{*}{ Total As } & \multirow{2}{*}{$\mathrm{As}_{\mathrm{Me}}$} \\
\hline & & & & & & & & $\mathrm{mg} \mathrm{kg}^{-1}$ & & \\
\hline $\begin{array}{l}\text { Surface soil } \\
(0-20 \mathrm{~cm})\end{array}$ & $\begin{array}{l}6.4 \pm 0.6 \\
(3.6-7.4)\end{array}$ & $\begin{array}{l}232 \pm 110 \\
(20-450)\end{array}$ & $\begin{array}{l}1.9 \pm 0.65 \\
(0.7-3.2)\end{array}$ & $\begin{array}{l}51 \pm 17 \\
(23-88)\end{array}$ & $\begin{array}{l}29 \pm 10 \\
(12-53)\end{array}$ & $\begin{array}{l}24 \pm 20 \\
(0.9-64)\end{array}$ & $\begin{array}{l}4.2 \pm 1.0 \\
(2.4-7.1)\end{array}$ & $\begin{array}{l}5100 \pm 2000 \\
(1200-18,100)\end{array}$ & $\begin{array}{l}4.48 \pm 3.0 \\
(1.52-17.1)\end{array}$ & $\begin{array}{l}0.17 \pm 0.09 \\
(0.06-0.42)\end{array}$ \\
\hline$n$ & 37 & 37 & 51 & 18 & 18 & 18 & 36 & 36 & 62 & 48 \\
\hline
\end{tabular}


Table 3

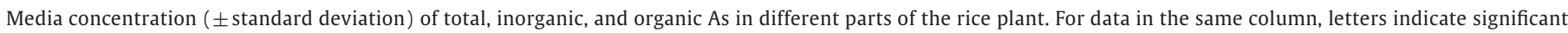
differences at $p<0.05$. na: not analyzed.

\begin{tabular}{|c|c|c|c|c|c|c|c|c|c|c|c|c|}
\hline & \multicolumn{4}{|l|}{ Total As } & \multicolumn{4}{|c|}{ Inorganic As } & \multicolumn{4}{|l|}{ Organic As } \\
\hline & \multicolumn{12}{|c|}{$\mathrm{mg} \mathrm{kg}^{-1}$ dry weight } \\
\hline & Grain & Husk & Stem & Leaf & Grain & Husk & Stem & Leaf & Grain & Husk & Stem & Leaf \\
\hline Guayas & $\begin{array}{l}0.125 \mathrm{a} \\
( \pm 0.044) \\
n=23\end{array}$ & $\begin{array}{l}0.079 \mathrm{a} \\
( \pm 0.023) \\
n=14\end{array}$ & $\begin{array}{l}0.201 \mathrm{a} \\
( \pm 0.073) \\
n=13\end{array}$ & $\begin{array}{l}0.286 a \\
( \pm 0.300) \\
n=11\end{array}$ & $\begin{array}{l}0.109 \mathrm{a} \\
( \pm 0.013) \\
n=9\end{array}$ & $\begin{array}{l}0.198 \\
( \pm 0.055) \\
n=5\end{array}$ & $\begin{array}{l}0.599 \\
( \pm 0.607) \\
n=5\end{array}$ & $\begin{array}{l}0.777 \\
( \pm 0.636) \\
n=5\end{array}$ & $\begin{array}{l}0.020 \mathrm{a} \\
( \pm 0.006) \\
n=7\end{array}$ & $\begin{array}{l}0.033 \\
( \pm 0.013) \\
n=5\end{array}$ & $\begin{array}{l}0.091 \\
( \pm 0.065) \\
n=5\end{array}$ & $\begin{array}{l}0.081 \\
( \pm 0.066) \\
n=5\end{array}$ \\
\hline Rios & $\begin{array}{l}0.042 \mathrm{~b} \\
( \pm 0.043) \\
n=14\end{array}$ & $\begin{array}{l}0.058 b \\
( \pm 0.035) \\
n=4\end{array}$ & $\begin{array}{l}0.091 b \\
( \pm 0.050) \\
n=8\end{array}$ & $\begin{array}{l}0.123 \mathrm{~b} \\
( \pm 0.080) \\
n=8\end{array}$ & na & na & na & na & na & na & na & na \\
\hline Market rice & $\begin{array}{l}0.067 b \\
( \pm 0.029) \\
n=16\end{array}$ & na & na & na & $\begin{array}{l}0.122 \mathrm{a} \\
( \pm 0.024) \\
n=3\end{array}$ & na & na & na & $\begin{array}{l}0.041 \mathrm{~b} \\
( \pm 0.008) \\
n=3\end{array}$ & na & na & na \\
\hline
\end{tabular}

for the element in soil solution ( $20 \mu \mathrm{g} \mathrm{I}^{-1}$ ) (see e.g. Pais and Jones, 1997; Macías and Calvo de Anta, 2008).

\subsubsection{Soil}

The soil organic C content was low (TOC: $1.9 \pm 0.6 \%$ ) and the texture was dominated by the clay fraction (23-88\%), followed by silt and sand fractions (Table 2). The dominant soil texture was clay and to a lesser extent clay loam and silty clay (Soil Survey Staff, 2014).

The redox conditions ranged between suboxic (Eh: 200-350 mV) and to a lesser extent anoxic ( $\mathrm{Eh}<100 \mathrm{mV}$ ). Although sulphidic material was not determined, the soil in some of the cultivated fields was extremely acidic ( $\mathrm{pH}$ : 3.6; Table 3 ), indicating the probable oxidation of metal sulphides, fundamentally pyrite ( $\mathrm{FeS}_{2}$; IUSS Group, 2007). However, the $\mathrm{pH}$ of most soils remained close to neutral ( $\mathrm{pH}$ 6.1-6.5), as usually observed for saturated soils in which reduction processes consume protons, with the $\mathrm{pH}$ being buffered by diffusion of $\mathrm{CO}_{2}$ (Vepraskas and Craft, 2016). The Eh-pH conditions indicate a favourable geochemical environment for the reduction of oxides and hydroxides of Mn but not for the Fe oxyhydroxides (Fig. 2).

The concentrations of total $\mathrm{Fe}(2.4-7.1 \%)$ and $\mathrm{Fe}_{\mathrm{Ox}}$ (1200$18,100 \mathrm{mg} \mathrm{kg}^{-1}$ ) showed wide spatial variation (Table 3 ), presumably due to the heterogeneity of the surrounding geological material. Granitic rocks (acid rock) and basalt/andesites (mafic/intermediate rock) have different chemical and mineralogical compositions, which may also explain the variability in the granulometric composition of the samples (Table 3).

The mean concentration of tAs in the soil was low (Table 2), with values situated within the characteristic range for uncontaminated soils, i.e. 5-10 $\mathrm{mg} \mathrm{kg}^{-1}$ (Pais and Jones, 1997; Matschullat, 2000; Mandal and Suzuki, 2002). Some values exceeded the threshold of $11 \mathrm{mg} \mathrm{kg}^{-1}$ established in some countries (i.e. Canada) as the maximum allowable concentration for cultivated fields (ECCC, 2011). However, the concentration of bioavailable $A s\left(A_{\mathrm{Me}}\right)$ was around $10 \%$ of the tAs, indicating an extremely low level of bioavailability in the rice field soils under study.

\subsection{Arsenic in plant tissues}

\subsubsection{Total As}

The tAs concentration in the samples was similar for field rice grain $\left(0.100 \pm 0.062 \mathrm{mg} \mathrm{kg}^{-1}\right.$ dry weight, d.w.), market rice $(0.067 \pm$ $0.028 \mathrm{mg} \mathrm{kg}^{-1}$ d.w.) and husks $\left(0.079 \pm 0.020 \mathrm{mg} \mathrm{kg}^{-1}\right.$ d.w. $)$

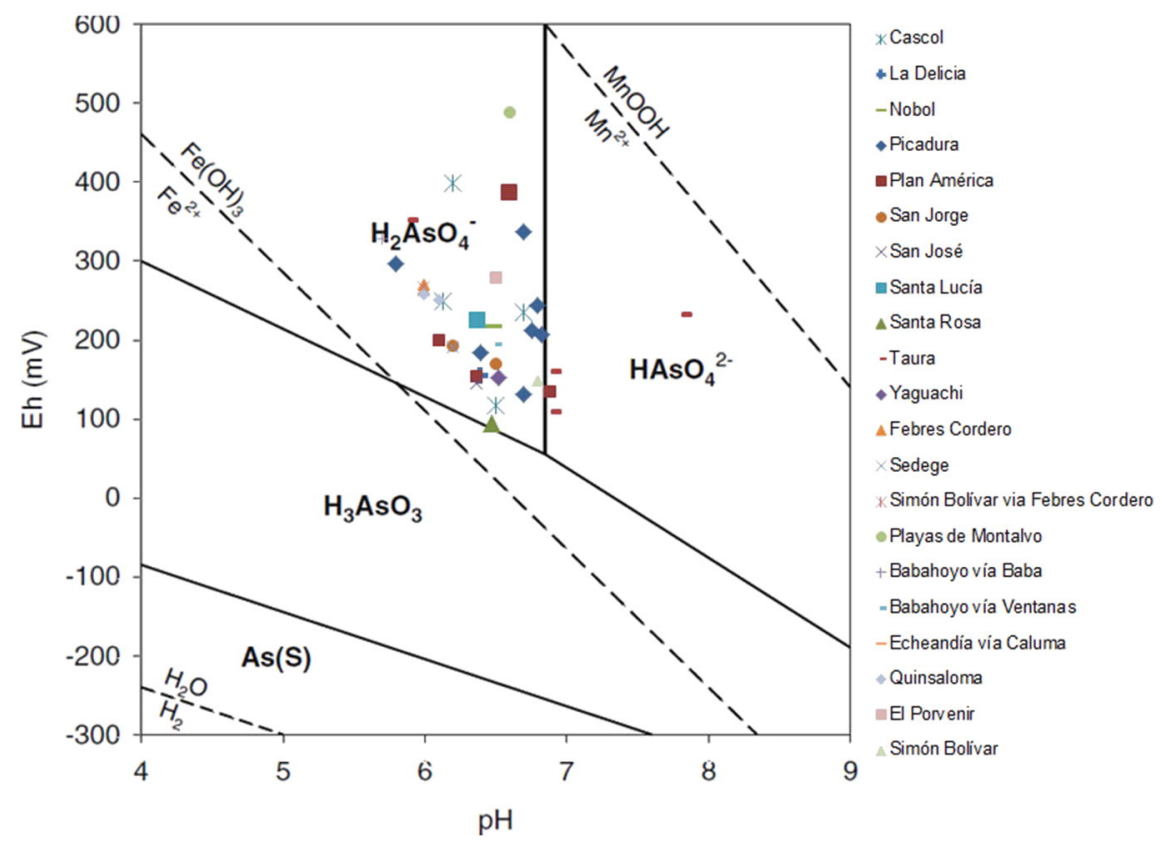

Fig. 2. Eh-pH conditions in soils and stability fields of oxyhydroxides of Fe/Mn and arsenate and arsenite. Modified from Masscheleyn et al. (1991). 

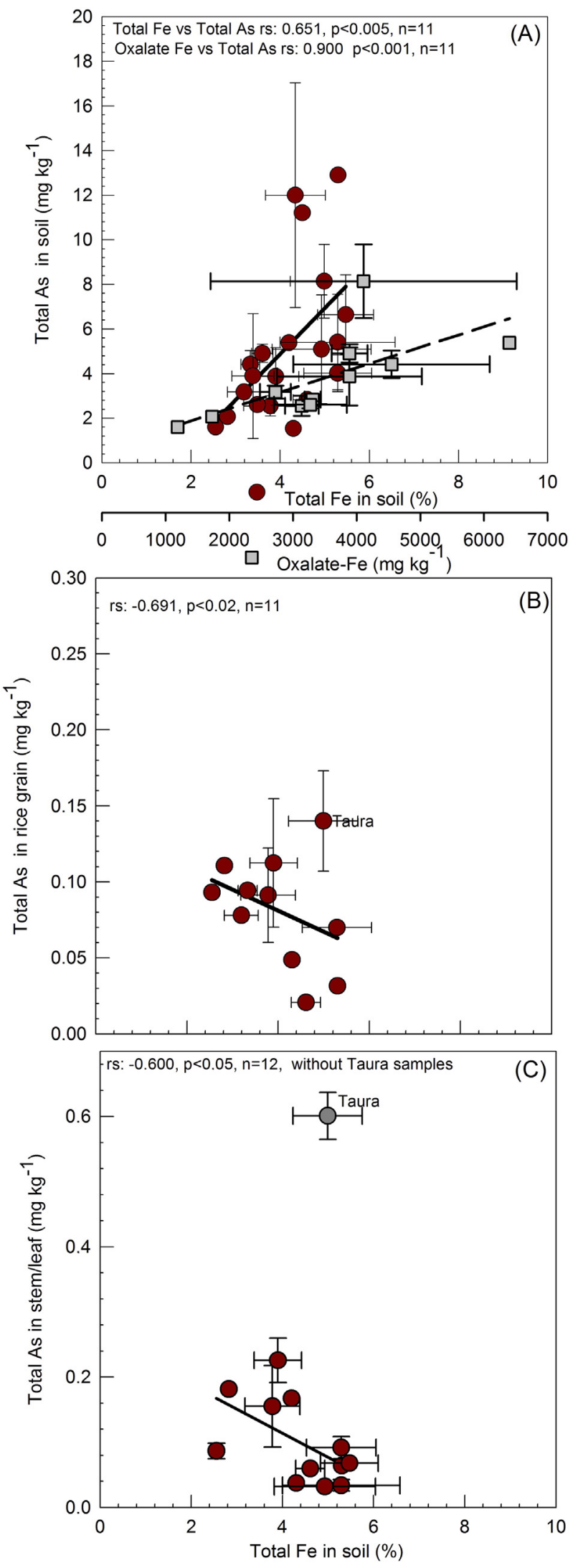

Fig. 3. Relationship between iron (total and oxyhydroxides) and A) total arsenic in the soil, B) total arsenic in grain rice, C) total arsenic in stem/leaf.
(ANOVA test, $p<0.05$ ) (Fig. A1A), while the concentrations in the leaves $\left(0.233 \pm 0.129 \mathrm{mg} \mathrm{kg}^{-1}\right.$ d.w. $)$ and stems $\left(0.258 \pm 0.133 \mathrm{mg} \mathrm{kg}^{-1}\right.$ d.w. $)$ were significantly higher (Fig. A1A).

The grains from the Guayas province yielded the highest tAs concentrations $\left(0.125 \pm 0.044 \mathrm{mg} \mathrm{kg}^{-1}\right.$ d.w.) which was significantly higher than the concentrations in field rice from the Los Ríos province $\left(0.042 \pm 0.040 \mathrm{mg} \mathrm{kg}^{-1}\right.$ d.w.) and market rice $(0.067 \pm$ $0.029 \mathrm{mg} \mathrm{kg}^{-1}$ d.w.) (Table 3). An abnormally high concentration was detected in the samples from Taura (Guayas province), especially in the stems and leaves (Taura, field rice: $0.139 \pm 0.04 \mathrm{mg} \mathrm{kg}^{-1}$ d.w.; leaf: $0.665 \pm 0.275 \mathrm{mg} \mathrm{kg}^{-1}$ d.w.; stem: $0.506 \pm 0.251 \mathrm{mg} \mathrm{kg}^{-1}$ d.w.; $n=4)$.

\subsubsection{Partitioning of arsenic in plants}

The mean concentration of iAs in the rice grain ranged between $0.125 \pm 0.044 \mathrm{mg} \mathrm{kg}^{-1}$ d.w. for Guayas province and $0.042 \pm$ $0.033 \mathrm{mg} \mathrm{kg}{ }^{-1}$ d.w. for Los Ríos province. The maximum level of $0.200 \mathrm{mg} \mathrm{kg}^{-1}$ for iAs proposed by Codex Alimentarius Commission (2014) was not exceeded in any of the samples. The iAs was the predominant form in all parts of the plant and in grains, representing $>80 \%$ of the tAs (Fig. A1B; Table 3). The highest concentrations of iAs were found in the leaves $\left(0.778 \pm 0.284 \mathrm{mg} \mathrm{kg}^{-1}\right.$ d.w. $)$ and stem $\left(0.599 \pm 0.250 \mathrm{mg} \mathrm{kg}^{-1}\right.$ d.w. $)$ and these were significantly higher than in the husk. The concentrations in the husk were significantly higher than those in the grains (Fig. A1A). A similar pattern was obtained for oAs, but with much lower values. The concentrations of both iAs and oAs were significantly higher in samples from Guayas than in those from Los Ríos province (Table 3).

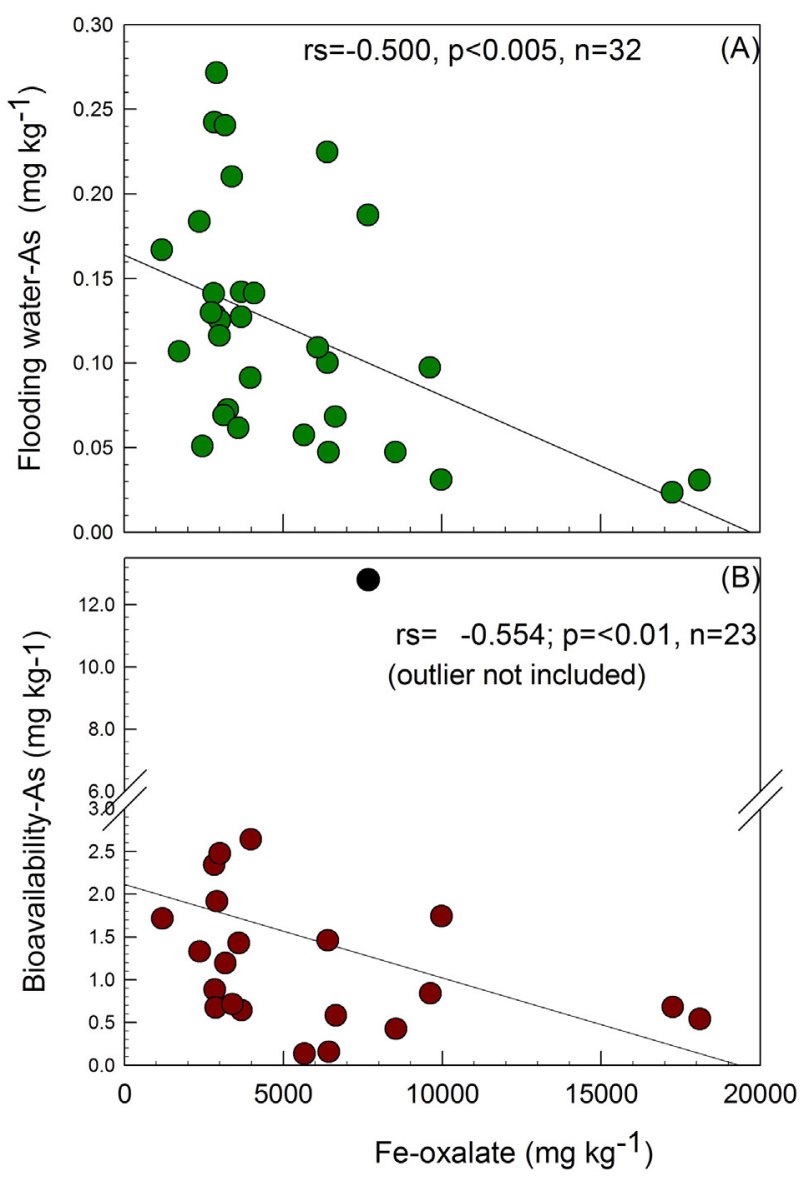

Fig. 4. Relationship between amorphous iron oxyhydroxides $\left(\mathrm{Fe}_{\mathrm{Ox}}\right)$ and $\left.\mathrm{A}\right)$ arsenic in flood water, B) bioavailable arsenic $\left(\mathrm{As}_{\mathrm{Me}}\right)$. 


\section{Discussion}

\subsection{Arsenic bioavailability in the agrosystem}

The concentration of As in water and soil samples remained within the ranges considered normal for naturally occurring arsenic in most of the study area. Moreover, the bioavailable $A s\left(A s_{\text {Me }}\right)$ was around $10 \%$ of the tAs, with concentrations below the threshold above which symptoms of toxicity are observed (As: $15-50 \mathrm{mg} \mathrm{kg}^{-1}$; KabataPendias and Pendias, 1992). However, $\mathrm{As}_{\mathrm{Me}}$ was closely related to the As content of the plant, especially in the grain, as indicated by the significant monotonic (linear) correlation between $\mathrm{As}_{\mathrm{Me}}$ and $\mathrm{tAs}(\mathrm{r}=$ $0.405, p<0.03 ; n=16$ ).

On the other hand, a small increase in the amount of As in the soil can give rise to high concentrations of As in the rice grains (Williams et al., 2007b), even in soils characterized by low concentrations of As (tAs $<10 \mathrm{mg} \mathrm{kg}^{-1}$ ). This may apply to the Taura site (Fig. 3) and is consistent with the capacity of the rice plant to concentrate As more efficiently than other cereals (Williams et al., 2007a, 2007b; Zavala and Duxbury, 2008). These studies showed a clear relationship between As concentrations in water and in the grain, although no significant correlation with As in the soil was observed. This finding suggests that the
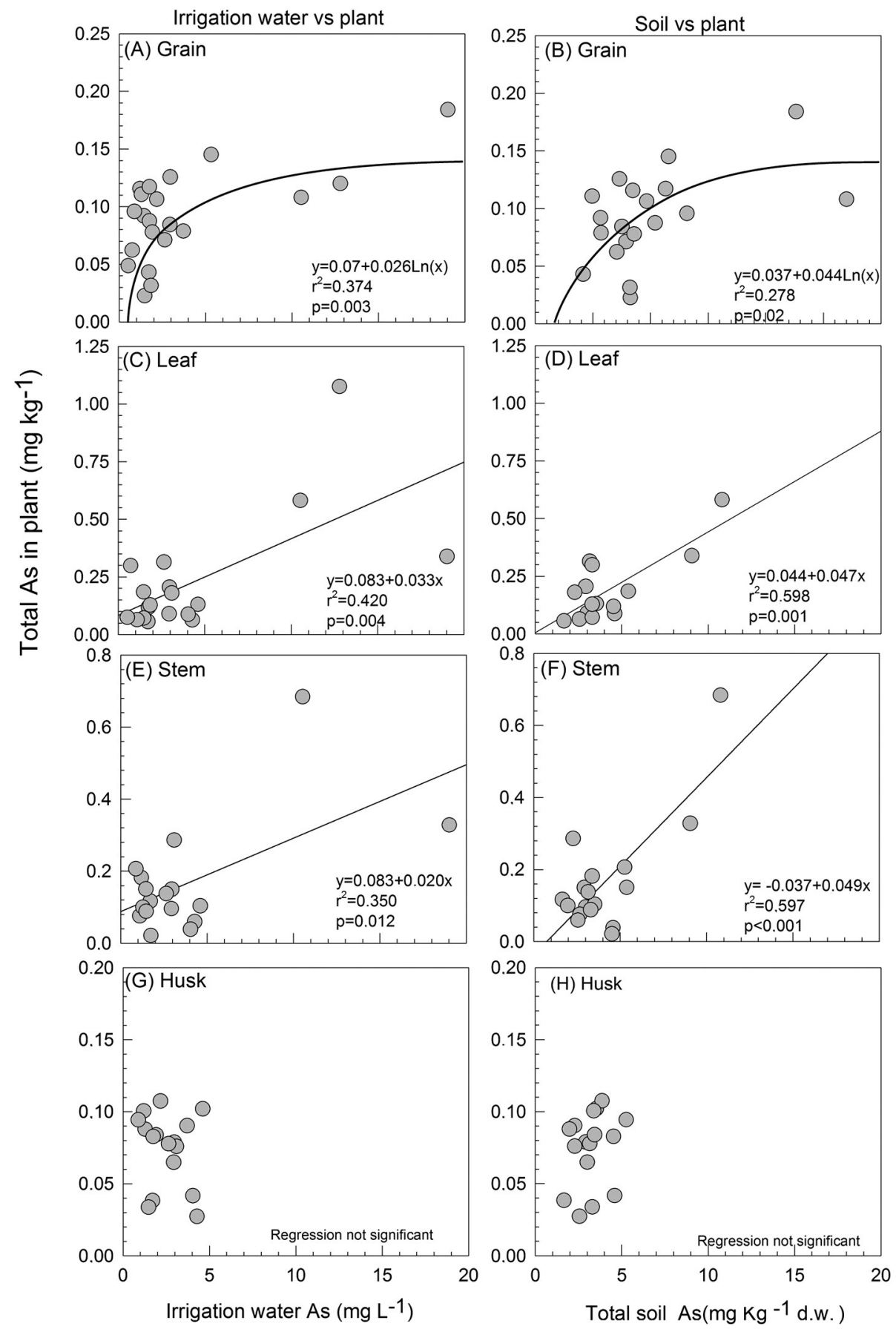

Fig. 5. Correlations between arsenic in flood water and total arsenic in soil with A, B) arsenic in rice grain, C, D) arsenic in leaf, E, F) arsenic in stem, G, H) arsenic in husk. 
bioavailability of As in soil is governed by a complex interaction between different soil parameters (e.g. pH, Eh, organic carbon, texture, $\mathrm{Fe} / \mathrm{Al}$ and Mn oxyhydroxides, $\mathrm{S}$ and $\mathrm{P}$ ), which may differ markedly in different soils (Song et al., 2006; Takahashi et al., 2004).

Iron plays a crucial role in As dynamics in soil systems (see e.g. Zhao et al., 2010; Henke, 2009). Our results show a highly significant correlation between total Fe and tAs concentrations in the soil (Fig. 3A), which indicates that total Fe contents may control the retention of As in soil. Previous studies have showed the capacity of amorphous $\mathrm{Fe}$ oxyhydroxides to adsorb inorganic forms of As, especially at $\mathrm{pH}<8-9$, at which the surface of Fe oxyhydroxides is positively charged (Goldberg, 2002; Meharg and Zhao, 2012). These findings are further corroborated by the highly significant positive correlation between $\mathrm{Fe}_{\mathrm{Ox}}$ and tAs in the soil ( $\mathrm{rs}=0.900, p<0.001$, Fig. 3A), indicating the importance of these minerals in retaining oxyanions such as arsenate. However, the less crystalline forms of Fe/Mn (i.e. Fe/Mn soluble in oxalate) are easily reduced under anoxic conditions (Canfield et al., 2005; Otero et al., 2009). The reduction of these Fe/Mn forms would lead to release of As into the interstitial water (Williams et al., 2007a, 2007b; Zhao et al., 2010). However, the Eh-pH conditions of the soils under study indicate that the Fe oxyhydroxides may remain stable despite being flooding during a period of approximately 3 months (Fig. 2). These results are consistent with the high concentrations of $\mathrm{Fe}_{\mathrm{Ox}}$ in the soils under study ( $\left.\mathrm{Fe}_{\mathrm{Ox}}: 5100 \pm 2000 \mathrm{mg} \mathrm{kg}^{-1}, n=48\right)$. The stability of easily reducible $\mathrm{Fe}$ forms $\left(\mathrm{Fe}_{\mathrm{Ox}}\right)$ in these soils may be a consequence of the low soil organic matter content (Table 2) and presumably low quality, which could limit the activity of Fe-reducing bacteria.

The negative and highly significant correlation between the total Fe in the soil and tAs in the rice (grain and stem, Fig. 3B, C) further reinforces the role of Fe in immobilizing As in the soil (Gustafsson and Bhattacharya, 2007). In addition, the negative correlations between $\mathrm{Fe}_{\mathrm{Ox}}$ and the bioavailable As in the soil and the As in the flood water (Fig. 4A, B) seem to indicate that amorphous Fe oxyhydroxides efficiently reduce the bioavailability of As (see also Matsumoto et al., 2016). The fact that $\mathrm{Fe}_{\mathrm{Ox}}$ was negatively but not significantly correlated with $\mathrm{tAs}$ in the grain and stem (data not shown) indicates that other soil components, such as crystalline Fe oxyhydroxides, may also govern As bioavailability. Hartley and Lepp (2008) observed that goethite (crystalline Fe oxyhydroxide) contributed substantially to reducing the As contents of plant shoots. In addition, the bioavailable fraction is usually high, sometimes representing $>40 \%$ of the tAs in the soil (Pais and Jones, 1997). Thus, the low concentrations of bioavailable As in the studied soils are consistent with the high contents of $\mathrm{Fe}_{\mathrm{Ox}}$ and with the clay texture of the soils, dominated by highly reactive clays such as smectite, which can significantly contribute to the adsorption of As (Goldberg, 2002). In the soils under study, the fraction of As

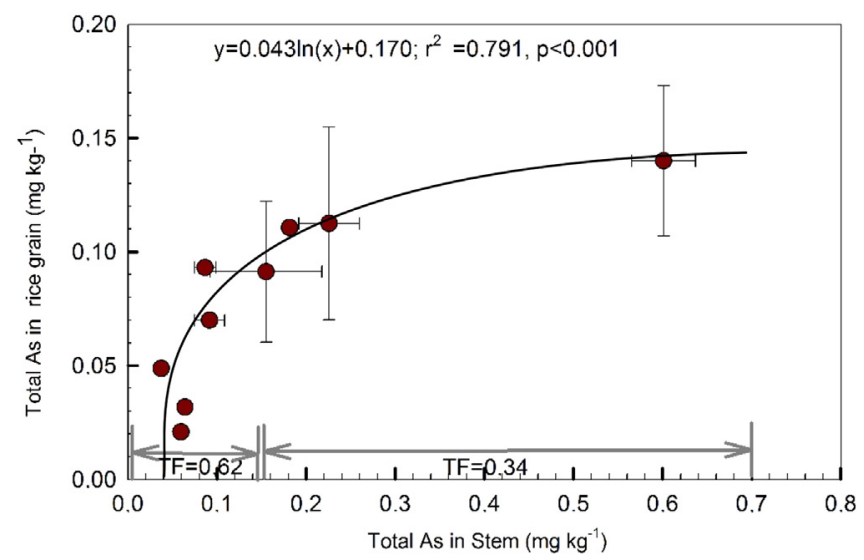

Fig. 6. Correlation between total arsenic in stem and total arsenic in grain. associated with silicates represented 55\% of the tAs (Otero and Ruales, 2016), according to the method of Keon et al. (2001).

4.2. Relationship between arsenic in water, soil and plants, and transfer from the rice plant to grain

The total concentration of As in rice grain grown in flooded soil or paddy conditions varies widely, between $\sim 0.01$ and $0.820 \mathrm{mg} \mathrm{kg}^{-1}$ (Meharg et al., 2009). The concentrations measured in the present study varied within much narrower limits (Table 3 ) and are included within the "normal" range (0.08-0.20 $\left.\mathrm{mg} \mathrm{kg}^{-1}\right)$ established by Zavala and Duxbury (2008). Moreover, none of the samples exceeded the threshold of $0.200 \mathrm{mg} \mathrm{kg}^{-1}$ established as the maximum allowed concentration of iAs (Codex Alimentarius Commission, 2014). The low tAs concentrations observed for the commercially produced Ecuadorian rice may be due to a dilution effect resulting from mixing rice from different plantations. In addition to the significant differences obtained for the two provinces considered, comparison of results for the same sites also revealed large variations in concentrations (e.g. Plan América: 0.088-0.188 $\mathrm{mg} \mathrm{kg}^{-1}$; Sedege: 0.022-0.157 $\mathrm{mg} \mathrm{kg}^{-1}$ ).

The relationships between the concentrations of As in environmental samples (flood water and soil) and tAs in rice grain were highly significant and fitted a logarithmic model (Fig. 5A, B); however, the relationship with tAs in stem or leaf fitted a linear model (Fig. 5C, D). No correlation was observed between the As in the environment (soil and/or flood water) and the As content in the husk (Fig. 5G, H). A hyperbolic trend, describing a moderate concentration iAs grain at high soil tAs has also recently been reported for rice in the Iberian Peninsula (Signes-Pastor et al., 2016).

The relationship between the tAs in the grain and the stem also fitted a logarithmic function (Fig. 6). The findings indicate that bioaccumulation of As in plants is linearly related to the concentration in the environment (soil and/or flood water); however, transfer of As from the plant to the grain appears to be strongly physiologically controlled, so that as the concentration in the stem increased, transfer from the stem to grain increased. Thus, the stem to grain transfer factor ( $\mathrm{TF}=\mathrm{As}$ -

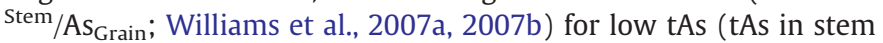
$<0.150 \mathrm{mg} \mathrm{kg} \mathrm{d.w.)} \mathrm{was} \mathrm{twice} \mathrm{that} \mathrm{observed} \mathrm{for} \mathrm{higher} \mathrm{concentrations}$ of As in the stem $\left(\mathrm{TF}_{<150}=0.64 \pm 0.31, n=10 ; \mathrm{TF}_{>150}=0.32 \pm\right.$ $0.12, n=4$; Fig. 6), whereas Williams et al. (2007a, 2007b) reported an exponential decrease. Future studies should aim to obtain a better understanding of the transfer of As from the plant to the rice grain, in order to identify rice varieties with the lowest possible grain/stem transfer factor for cultivating in areas where arsenic intake poses a threat to human health.

The iAs represented $>80 \%$ of the tAs in the rice grain, which is a very high percentage considering that the geographical range varies from 10 to $90 \%$ (Williams et al., 2005). This high level is of concern, as iAs is considered the most toxic fraction due to its carcinogenic nature (see e.g. Meharg and Zhao, 2012). Higher percentages were obtained for other plant parts, with mean values ranging from $83 \%$ in the stem to $90 \%$ in the leaf.

Finally, it may be possible to reduce the amount of As in rice fields by discarding the waste material remaining after harvesting, as the rice straw (stems and leaves) contains high levels of the element. Thus, assuming a mean concentration of $0.50 \mathrm{mg} \mathrm{kg}^{-1}$ and an average rate of rice production of 3 metric ton ha ${ }^{-1}$ (Nader, 2010), the quantity of As extracted by removal of rice straw would be approximately $1.5 \mathrm{~g} \mathrm{ha}^{-1}$. This could initially appear low relative to the tAs in soil; however, considering the total area cultivated in Ecuador $(\approx 410,000$ ha; INEC, 2013$)$ and the fact that rice crops are harvested twice a year, the amount of As thus extracted from the soil would be approximately $1230 \mathrm{~kg} \mathrm{yr}^{-1}$. Moreover, the fraction extracted represents the most bioavailable and toxic fraction (mainly iAs). Application of this measure in high-risk situations may therefore be of great interest. 


\section{Conclusions}

The study findings clearly show a relationship between the concentrations of As in flood water, plants and grain, which is consistent with the findings of other studies. However, the present findings also clearly indicate a relationship between the As content in the plant and in the soil (tAs and bioavailable As). In contrast to the conclusions of other authors, the amorphous Fe oxyhydroxides in the soils under study remain stable in the soil during flooding and play a fundamental role in decrease in the bioavailability of As. On the other hand, the total concentration of As in the plants (leaves and stems) was linearly related to the concentration of As in the soil and water. The relationships with the As in rice grain and with the As contents of the stem and in the grain were logarithmic. These findings seem to indicate the existence of certain physiological mechanisms that "protect" the grain from increased concentrations of As in the environment (soil/water).

Supplementary data to this article can be found online at http://dx. doi.org/10.1016/j.scitotenv.2016.08.162.

\section{Acknowledgements}

This work is part of a research Project entitled "Bioavailability of arsenic and toxic metals in rice fields in Ecuador and their effects on human health", funded by the Escuela Politécnica Nacional (PIJ-15-10) and CRETUS strategic group (AGRUP2015/02). We thank M. Carrillo, for his invaluable collaboration during the fieldwork, María José Santiso, for assistance with laboratory work, and Dr. Augusto Pérez-Alberti, for elaborating Fig. 1. XLOP is grateful for the financial support from the Proyecto PROMETEO (SENESCYT Ecuador). The authors also thank two anonymous reviewers and Dr. F. Tack for their valuable comments on an earlier draft of this manuscript.

\section{References}

Appleton, J.D.T.M., Williams, T.M., Orbea, H., Carrasco, M., 2001. Fluvial contamination associated with artisanal gold mining in the Ponce Enríquez, Portovelo-Zaruma and Nambija areas, Ecuador. Water Air Soil Pollut. 13, 19-39.

Ayers, R.S., Westcot, D.W., 1994. Water quality for agriculture, FAO Irrigation and Drainage Paper 29. Food and Agriculture Organization of the United Nations, Roma.

Blakemore, L.C., 1978. Exchange complex dominated by amorphous material (ECDAM). In: Smith, G.D. (Ed.), The Andisol Proposal. Soil Bureau, DSIR, New Zealand, pp. 21-22.

Bruland, K.W., Franks, R.P., Knauer, G.A., Martin, J.H., 1979. Sampling and analytical methods for the nanogram per litre determination of copper, cadmium, zinc, and nickel in seawaters. Anal. Chim. Acta 105, 233-241.

Bundschuh, J., Litter, M.I., Parvez, F., Román-Ross, G., Nicolli, H.B., Jean, J.-S., Liu, C.-W., López, D., Armienta, M.A., Guilherme, L.R.G., Gomez Cuevas, A., Cornejo, L., Cumbal, L., Toujaguez, R., 2012a. One century of arsenic exposure in Latin America: a review of history and occurrence from 14 countries. Sci. Total Environ. 429, 2-35.

Bundschuh, J., Litter, M.I., Bhattacharya, P., 2012b. Arsenic in Latin America, an unrevealed continent: occurrence, health effects and mitigation. Sci. Total Environ. 429, 1.

Bundschuh, J., Nath, B., Bhattacharya, P., Liu, C.-W., Armienta, M.A., Moreno López, M.V., Lopez, D.L., Jean, J.-S., Cornejo, L., Macedo, L.F.L., TenutaFilho, A., 2012c. Arsenic in the food chain: the Latin America perspective. Sci. Total Environ. 429, 92-106.

Canfield, D.E., Kristensen, E., Thamdrup, B., 2005. Aquatic Geomicrobiology. Academic Press.

Codex Alimentarius Commission, 2014. Thirty-seventh Session CICG, Geneva, Switzerland 14-18 July 2014, http://www.fao.org/news/story/en/item/238558/icode/.

Cumbal, L., Vallejo, P., Rodriguez, B., López, D., 2010. Arsenic in geothermal sources at the North-Central Andean Region of Ecuador: concentrations and mechanisms of mobility. Environ. Earth Sci. 61 (2), 299-310.

De la Torre E., Guevara A., Muñoz G., Criollo E., 2004. Estudio de aguas superficiales y sedimentos de la cuenca de los ríos Sucus, Tambo y Papallacta. Quito, Ecuador: Unpublished report for the Ecuadorian Congress.

ECCC, 2011. Environment and Climate Change Canada, Soil, ground water and sediment standard for use under Part XV.1 of the Environmental Protection Act. Government of Canada.

FAO (Food and Agriculture Organization of the United Nations), 2004n. http://faostat.fao. org/site/336/DesktopDefault.aspx?PageID = 336 .

Gee, G.W., Bauder, J.W., 1986. Particle-size analysis. In: Klute, A. (Ed.), Methods of Soil Analysis. Part 1. Physical and Mineralogical Methods. American Society of Agronomy, and Soils Science of America, Madison, Wisconsin, USA, pp. 383-411.
Goldberg, S., 2002. Competitive absorption of arsenate and arsenite on oxides and clay minerals. Soil Sci. Soc. Am. J. 66, 413-421.

Gustafsson, J.P., Bhattacharya, P., 2007. Geochemical modelling of arsenic adsorption to oxide surface. In: Bhattacharya, P., Mukherjee, A.B., Bundschuch, J., Zevenhoven, R., Loeppert, R.H. (Eds.), Arsenic on Soil and Groundwater EnvironmentTrace Metals and Other Contaminats in the Environment vol. 9. Elsevier, pp. 159-206.

Hartley, W., Lepp, N.W., 2008. Remediation of arsenic contaminated soils by iron-oxide application, evaluated in terms of plant productivity, arsenic and phytotoxic metal uptake. Sci. Total Environ. 390, 35-44.

Arsenic. In: Henke, K. (Ed.), Environmental Chemistry, Health Threats and Waste Treatment. Wiley.

Huang, J.-H., Ilgen, G., Fecher, P., 2010. Quantitative chemical extraction for arsenic speciation in rice grains. J. Anal. At. Spectrom. 25, 800-802.

INEC, 2013. Anuario estadístico 2013 Ecuador (Quito, Ecuador).

IUSS Grupo de Trabajo WRB, 2007. Base Referencial Mundial del Recurso Suelo. Primera actualización 2007. Informes sobre Recursos Mundiales de Suelos No. 103FAO, Roma.

Kabata-Pendias, A., Pendias, H., 1992. Trace Elements in Soils and Plants. CRC. Press, Inc. Boca Raton, Florida.

Keon, N., Swartz, C., Brabander, D., Harvey, C., Hemond, H., 2001. Validation of an arsenic sequential extraction method for evaluating mobility in sediments. Environ. Sci. Technol. 35, 2778-2784.

Macías, F., Calvo de Anta, R., 2008. Niveles genéricos de referencia de metales pesados y otros elementos traza en suelos de Galicia. Consellería de Medio Ambiente, Xunta de Galicia.

Mandal, B., Suzuki, K., 2002. Arsenic round the world: a review. Talanta 58, 201-2035.

Masscheleyn, P.H., Delaune, R.D., Patrick, W.H., 1991. Effect of redox potential and pH on arsenic speciation and solubility in a contaminated soil. Environ. Sci. Technol. 25, 1414-1419.

Matschullat, J., 2000. Arsenic in the geosphere - a review. Sci. Total Environ. 249, 297-312.

Matsumoto, S., Kasuga, J., Makino, T., Arao, T., 2016. Evaluation of the effects of application of iron materials on the accumulation and speciation of arsenic in rice grain grown on uncontaminated soil with relatively high levels of arsenic. Environ. Exp. Bot. 125 42-51.

McClintock, T., Chen, Y., Bundschuh, J., Oliver, J.T., Navoni, J., Olmos, V., Lepori, E.V., Ahsan, H., Parvezet, F., 2012. Arsenic exposure in Latin America: biomarkers, risk assessments and related health effects. Sci. Total Environ. 429, 76-91.

Meharg, A.A., Zhao, F.-J., 2012. Arsenic and Rice. Springer

Meharg, A.A., Williams, P.N., Adamako, E., Lawgali, Y.Y., Deacon, C., Villada, A., Cambell, R.C.J., Sun, G.X., Zhu, Y.G., Feldmann, J., Raab, A., Zhao, F.J., Islam, R., Hossain, S. Yanai, J., 2009. Geographical variation in total and inorganic arsenic content of polished (white) rice. Environ. Sci. Technol. 43, 1612-1617.

Mehlich, A., 1984. Mehlich 3 soil test extractant: a modification of the Mehlich 2 extractant. Commun. Soil Sci. Plant Anal. 15, 1409-1416.

Nader, G.A., 2010. Rice Producer's Guide to Marketing Rice Straw. University of California (http://anrcatalog.ucanr.edu/pdf/8425.pdf).

Naidu, R., Smith, E., Owens, G., Bhattacharya, P., Nadebaum, P. (Eds), 2006. Managing Arsenic in the Environment-From Soil to Human; Eds.; CSIRO Publishing: Melbourne, Australia.

National Research Council, 2001. Arsenic in Drinking Water Update. National Academies Press, Washington, DC

Nicolli, H.B., Bundschuh, J., Blanco, M.C., Tujchneider, O.C., Panarello, H.O., Dapeña, C., Rusansky, J.E., 2012. Arsenic and associated trace-elements in groundwater from the Chaco-Pampean plain, Argentina: results from 100 years of research. Sci. Total Environ. 429, 36-56.

Otero, X.L., Ruales, J., 2016. Calidad de los agrosistemas productores de arroz de las provincias de Los Ríos y Guayas. Contenido de elementos tóxicos con especial énfasis en la dinámica del arsénico. Inedict report. Senescyt (Ecuador. 88 pp.).

Otero, X.L., Ferreira, T.O., Huerta-Díaz, M.A., Partiti, C.S.M., Souza, V., Vidal, P., Macías, F., 2009. Geochemistry of iron and manganese in soils and sediments of a mangrove system, island of PaiMatos (Cananeia,-SP-Brazil). Geoderma 148, 318-335.

Pais, I., Jones Jr., J.B., 1997. The Handbook of Trace Elements. St. Lucie Press, Boca Raton, Florida.

Signes-Pastor, A.J., Carey, M., Carbonell-Barrachina, A.A., Moreno-Jiménez, E., Green, A.J., Meharg, A.A., 2016. Geographical variation in inorganic arsenic in paddy field samples and commercial rice from the Iberian Peninsula. Food Chem. 202, 356-363.

Soil Survey Staff, 2014. Keys to Soil Taxonomy. Twelfth ed. United States Department of Agriculture Natural Resources Conservation Service (USA).

Song, J., Zhao, F.-J., McGrath, S.P., Luo, Y.-M., 2006. Influence of soil properties and aging on arsenic phytotoxicity. Environ. Toxicol. Chem. 25, 1663-1670.

Takahashi, Y., Minamikawa, R., Hattori, K.H., Kurishima, K., Kihou, N., Yuita, K., 2004. Arsenic behaviour in paddy fields during the cycle of flooded and non-flooded periods. Environ. Sci. Technol. 38, 1038-1044.

Torres, M., Marin, M., 1974. Levantamiento geológico de las provincias de Guayas y Los Ríos. Dirección General de Geología y Minas. Ministerio de Recursos Naturales y Energéticos, Quito.

Vepraskas, M.., Craft, B., 2016. Wetland Soils: Genesis, Hydrology, Landscapes, and Classification. second edition. CRS press.

Wetzel, R.G., 2001. Limnology. Lake and River Ecosystems, Third ed. Academic Press.

Williams, P.N., Price, A.H., Raab, A., Hossain, S.A., Feldmann, J., Meharg, A.A., 2005. Variation in arsenic speciation and concentration in paddy rice related to dietary exposure. Environ. Sci. Technol. 39, 5531-5540.

Williams PN, Raab A., Feldmann J., Meharg A.A., 2007a. Market basket survey shows elevated levels of As in South Central US processed rice compared to California: consequences for human dietary exposure. Environ. Sci. Technol. 41, 2178-2183. 
Williams, P.N., Villada, A., Deacon, C., Raab, A., Figuerola, J., Green, A.J., Feldmann, J., Meharg, A.A., 2007b. Greatly enhanced arsenic shoot assimilation in rice leads to elevated grain levels compared to wheat and barley. Environ. Sci. Technol. 41, 6854-6859.

World Health Organization, 2004. IARC, Working Group on some drinking water disinfectants and contaminants, including arsenic. vol. 84. Monograph, Lyon, p. 1.

Zar, J., 1996. Biostatistical Analysis. Prentice-Hall, Upper Saddle River, NJ.
Zavala, Y.J., Duxbury, J.M., 2008. Arsenic in rice: I. Estimating normal levels of total arsenic in rice grain. Environ. Sci. Technol. 42, 3856-3860.

Zhao, F., McGrath, S., Meharg, A.A., 2010. Arsenic as a food chain contaminant: mechanisms of plant uptake and metabolism and mitigation strategies. Annu. Rev. Plant Biol. 61, 535-559. 